\title{
KELANGKAAN SUMBERDAYA DAN KONFLIK KEKERASAN
}

\author{
Suparman Marzuki
}

Pendahuluan

INAMIKA kehidupan masyarakat, bangsa dan negara pada dekade terakhir dan mungkin dekade- dekade mendatang akan makin menunjukkan wajah paradoksalnya. Strategi pertumbuhan ekonomi (economic growth) yang tetap diyakini banyak. negara, khususnya negara-negara dunia ketiga sebagai satusatunya cara yang dapat secara cepat mendorong perkembangan ekonomi suatu negara tidak dapat dipungkuri telah berhasil mencapai tingkat pertumbuhan yang mencengangkan, meski secara bersamaan telah menimbulkan pelbagai krisis lingkungan pada skala global, nasional maupun lokal.

Sebelum dekade ini lingkungan hidup lebih diperlakukan sebagai masalah lokal untuk diselesaikan di tempat, termasuk dalam hal ini pemikiran di bidang lingkungan hidup berlaku terutama untuk menanggapi masalah-masalah yang khas dijumpai di negara-negara maju, yang kurang berarti bagi negara-negara yang sedang berkembang. Bahkan dalam dasawarsa tujuh puluhan yang dapat dikatakan sebagai dekade awal kesadaran lingkungan internasional masih terfokus pada isu-isu pencemaran dan kerusakan lingkungan' yang kekhawatiran atasnya lebih pada masalah makro, yaitu kelangsungan pembangunan itu sendiri. Tidak pernah disadari sebelumnya bahwa persoalan lingkungan hidup jauh lebih luas dan kompleks menyangkut makin langkanya sumberdaya baik yang dapat diperbahanui lebih-lebih yang tidak dapat diperbahanui lagi yang secara mikro pada pelbagai kawasan menjadi faktor langsung atau tidak langsung terjadinya pelbagai konflik kekerasan.

\section{Perubahan, Kelangkaan lingkungan dan Konfllk Kekersan}

Enam tipe perubahan lingkungan yang diperkirakan potensial menimbulkan konflik-konflik kekerasan, yaitu (1) perubahan iklim akibat efek rumah kaca; (2) menipisnya lapisan ozon; (3) menurun dan rusaknya kualitas tanah-tanah pertanian akibat tidak adanya sistem konversi tanah yang dipakai; (4) penebangan dan penggundulan hutan; (5) menipisnya dan tercemarnya persedian air bersih, (6) Pertumbuhan penduduk yang cepat mengakibatkan sumberdaya alam yang tersedia harus dibagi kepada banyak orang, (7) munculnya konsentrasi penguasaan sumber daya pada segelintir orang.

Efek rumah kaca telah terbukti menimbulkan perubahan iklim (pemanasan bumi) yang kemungkinan besar jika tidak dapat dikendalikan akan merubah pola cuaca dan pola pertanian serta perikanan. Apa efek lokal perubahan cuaca di Indonesia belum dapat diterka, di mana hujan akan bertambah dan di mana akan dialami musim kemarau yang lebih panjang yang dapat merubah lahan pertanian menjadi lahan gersang.

Kemungkina besar juga bahwa pola perikanan akan berpindah ke bagian laut yang lebih dingin kalau suhu air laut meningkat. Pelbagai pulau kecil dan juga pelbagai daerah pantai dan pesisir akan 
tergenang. Ada kemungkinan terjadi pemindahan kota-kota tertentu ke tempattempat yang lebih tinggi.. Perubahanperubahan dimaksud tentu akan menimbulkan ketegangan-ketegangan atau bahkan konflik-konflik kekerasan terbuka, bukan hanya antara negara dan masyarakat bahkan antar masyarakat sendiri akibat kelangkaan lingkungan yang tersedia bagi perubahan semacam itu.

Permasalahan tanah sebagai salah satu aspek yang sangat potensial memicu konflik di Indonesia misalnya, sejak dua dekade ini mengalami perubahan, baik ditinjau dari segi permasalahan itu sendiri maupun dari segi siapa yang terlibat. Dari segi permasalahan, di samping masalah lama, yaitu "lapar tanah" yang belum terpecahkan, muncul masalah baru yang disebut dengan "dislanddowning process". suatu peristiwa karena alasan yang dikaitkan dengan pembangunan, para pemilik tanah menjadi kehilangan tanah. Sedangkan dari segi yang terlibat, bukan lagi antara tuan tanah melawan petani penggarap seperti pada tahun 1960-an, melainkan antara pemilik tanah melawan pemerintah, seperti pada kasus Kedung Ombo (Lukman, 1995).

Dalam skala global, kelangkaan sumber daya menurut pengamatan-Thomas F. Homer Dixon (1994) muncul karena berkurangnya kualitas dan kuantitas sumber daya yang dapat diperbaharui ditambah pertumbuhan penduduk serta tak memadainya aksesakses sumberdaya atau bisa juga terjadi karena tidak memadainya akses sumberdaya ditambah pertumbuhan penduduk serta berkurangnya kualitas dan kuantitas sumberdaya yang dapat diperbaharui.

Dampak sosial tahap pertama menurut Dixon yang dapat terjadi akibat kelangkaan sumberdaya lingkungan ini adalah timbulnya migrasi atau. perpindahan penduduk secara bésarbesaran atau bahkan bisa terjadi pengusiran atau bisa juga secara simultan menimbulkan berkurangnya peroduktifitas ekonomi yang pada gilirannya melemahkan negara (weakened states) yang akhirnya bisa menimbulkan konflikkonflik antar suku, kudeta atau pelbagai bentuk kekerasan ekonomi (perampokan, pencurian, dst).

Apa yang dikemukakan Dixon sesungguhnya telah terjadi di hampir semua negara tidak terkecuali Indonesia, hanya saja analisis struktural semacam ini belum begitu disadari banyak pihak, tidak terkecuali kalangan akademisi, terutama karena dominasi pikiran struktural fungsional kurang memberikan ruang yang cukup bagi analis-analis struktural konflik. Padahal jika dianalisis melalui pelbagai peristiwa kekerasan beberapa tahun belakangan ini tidak dapat dibantah bahwa konflik-konflik kekerasan antara negara dengan masyarakat, pemilik modal dengan masyarakat atau bahkan antar masyarakat sendiri mulai dipicu oleh kegalauan orang tentang kemungkinan untuk "survival" secara ekonomi di masa depan.

Konflik kekerasan yang menghadapkan langsung masyarakat di satu pihak dengan kapital dan atau negara di pihak lain tampak makin meningkat sebagaimana ditunjukkan dalam kasus Timika di Irian Jaya, kasus Kedung Ombo, Kasus Pulau Panggang, Lampung, Pulau Yamdena, Maluku, Bentian di Kalimantan Timur dan seterusnya. Belakangan setelah. terjadi Banjir Besar di Jakarta akibat meluapnya kali Ciliwung telah pula memperuncing kecemburuan sosial masyarakat miskin atau setidaknya yang tinggal di sepanjang aliran sungai Ciliwung dengan sebagian kecil orang yang hidup melimpah membangun villa-villa mewah di Puncak dan sekitarnya. Hal serupa sudah mulai terasa di Yogyakarta, bahwa pada musim hujan tahun-tahun belakangan ini sebagian daerah Yogyakarta Selatan sudah mulai dilanda banjir, sesuatu yang belum pernah terjadi sebelumnya. Diduga hal itu disebabkan 
Topik : Kelangtean Sumberdaya...., Suparman Harzubi

karena pembangunan di sekitar Yogya Utara, khususnya di kawasan Kaliurang dan sekiitarnya telah sedemikan rupa mengurangi daya serap air daerah tersebut sehingga luapan air sepenuhnya tumpah ke sungai-sungai yang mengalir ke Selatan yang daya tampungnya terbatas.

Pertambahan pembangunan hotelhotel atau guest house-guest house di sekitar Yogyakarta Selatan itu juga beberapa tahun belakangan ini mulai meresahkan karena kualitas dan kuantitas air sumur masyarakat Karangkajen dan sekitarnya jauh menurun karena tersedot oleh sumur-sumur bor yang dibuat oleh guest house-goest house dan hotel-hotel yang tentu saja membutuhkan persedian air sangat banyak. Belum lagi lingkungan sosial sekitar mengalami penetrasi nilai dan pola-pola budaya yang hampir sepenuhnya menghadirkan nuansa modern (Barat) untuk mengakaomodasi kebutuhan para turis asing yang menjadi konsumen terbesar mereka menjadi salah satu aspek pemicu ketegangan.

Kita juga bisa mencermati bahwa konflik konflik kekerasan sesama orang miskin tampak makin meningkat dan bervariasi. Konflik antara para preman selalu berkaitan dengan wilayah operasi; konflik antara sesama pengemudi angkutan kota berkaitan dengan jalur "basah" dan jalur "kering"; konflik antar tukang parkir, antar pedagang kaki lima, penyemir sepatu dan lain sebagainya juga karena hal yang sama. Kontlik kekerasan antara remaja pelajar juga dipicu oleh suasana tata ruang (kota) dan bangunan yang tidak lagi menyediakan cukup ruang bagi mereka untuk bereksperesi, berdialog dengan alam, dengan cuaca yang nyaman, dengan keramahan lingkungan.

Dengan kata lain, dorongandorongan struktural demikian itu telah memicu ketegangan-ketegangan struktural di dalam masyarakat yang langsung atau tidak langsung telah pula mencetuskan pelbagai pola kriminalitas konvensional pada bagian tertentu masyarakat, dan kejahatan inkonvensional (korupsi atau manipulasi) pada lapisan tertentu masyarakat lainnya. Hipotesis pengaruh sistem kapitalisme (keserakahan) atas kelangkaankeiangkaan sumberdaya lingkungan dan kekerasan tampaknya kian tak terbantah, setelah melihat gejala yang sekarang terjadi di Eropa Timur, Chiina dan bekas Uni Soviet. Reformasi ke arah sistem ekonimi kapitalis di sana ternyata telah membuat gelombang tindak kejahatan kekerasan sebagai bagian realitas kehidupan sehari-hari dalam masyarakat akibat dorongan yang melekat dalam suatu sistem kapitalis untuk mencapai maksimum akumulasi modal, maksimum produksi dan konsumsi serta berbagai dimensi kekuatan mekanisme pasar lainnya (termasuk dimensi kekuasaan politik) di dalamnya telah memaksa diri setiap manusia menjadi homo economicus yang semata-mata digerakkan oleh rasionalitas instrumental pencarian laba sehingga eksploitasi sumber daya menjadi tak terelakkan yang membuat sebagian besar masyarakat termarjinalisasi.

Menurut Ricard Queney (1977) sistem kapitalis tampaknya memang memproduksi dan memelihara sumbersumber kejahatan karena ia fungsional atas sistem itu. la mencatat tiga jenis kejahatan, yaitu the crimes of economic domination, the crime of government dan the crimes of acomodation (kejahatan yang muncul sebagai pilihan rasional pelaku untuk menyesuaikan diri dengan pola pencapaian maksimum konsumsi yang didorong kuat oleh sistem kapitalis, ataupun hanya sekedar upaya untuk bertahan hidup dalam sistem di mana institusi-isntitusi perlindungan sosial kolektif telah diperlemah demi efisiensi pertumbuhan kapitalis). Letak fungsionalnya justru karena ia memberikan kontribusi bagi kelangsungan sistem kapitalis, yakni memelihara daya beli atau kemampuan konsumsi kelompok 
kriminal, yang notabene adalah kelompok sosial yang tidak memiliki modal produksi. Yang mengherankan justru jenis kejahatan yang terakhir ini yang menjadi orientasi penanggulangan kejahatan pada sebagian besar negara dunia ketiga, termasuk Indonesia, padahal kejahatan ini tidak lain sekedar implikasi dari the crimes of economic domination dan the crime of govemment.

Persoalan kekerasan dalam skala global maupun nasional tampaknya memang merupakan bagian tak terpisahkan dari proses internasionalisasi kapital, ketika akumulasi modal secara ekspansif melahirkan militerisasi untuk menjamin kokohnya tatanan sosial politik yang mendukungnya. Tata dunia dan kompleks industri militer adalah fenomena internasional yang memperkuat strukturstruktur kekerasan. Perkembangan militerisasi dan penggunaan kekerasan yang mengikuti ekspansi merkantalis dan kapitalis, erat hubungannya dengan proses akumulasi kapital dan konsentrasi ekonomi termasuk menyangga pelbagai bentuk eksploitasi sumber daya. Sakamoto yang mengamati struktur historis dari militerisasi menyimpulkan adanya kaitan kuat antara tumbuhnya militerisme dengan tahap-tahap akumulasi kapital pada berbagai negara. negaranegara yang memimpin akumulasi kapital dan berkembang terlebih dahulu, lalu membentuk struktur dominan tanpa militerisasi yang ekstensif. Tapi negaranegara yang menyusul kemudian tahap yang lebih terbelakang untuk memasuki tahap akumulasi kapital dan industrialisasi, umumnya telah menjumpai dirinya dalam pengaruh struktur dominasi. Mereka itu kemudian biasanya mengalami proses militerisasi untuk bisa menciptakan perkembangan kapital yang otonom

Kekerasan juga nampak diterima setidak-tidaknya pada sebagian negara-

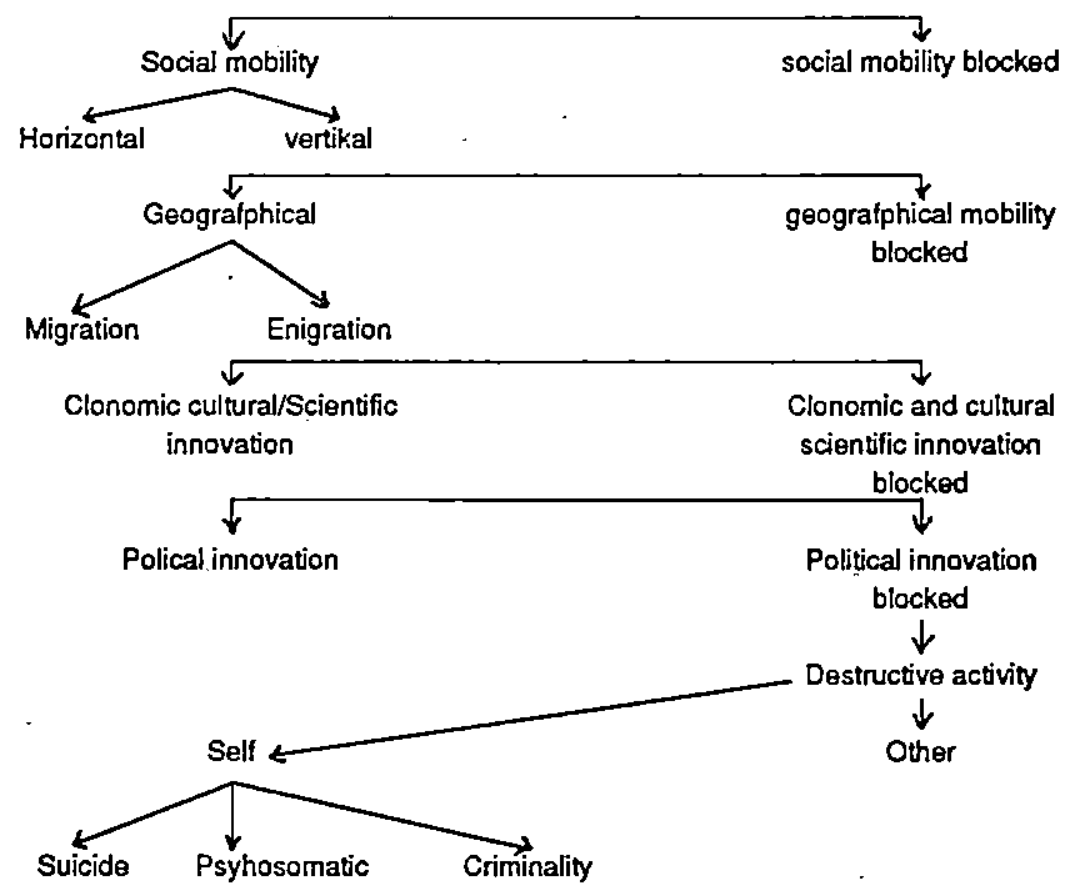

Revolution

of

the system 
negara di-dunia sebagai ideologi, perspektif, paradigma dan ancangan bahkan metodologi dalam menyelesaikan masalah-masalah poltik ekonomi dan sosial yang mendampingi kekuatankekuatan hegomonik lain dalam menjalankan dominasi. Sementara itu, aparatur represif negara kian berkembang secara canggih mulai dari perang, intevensi militer sampai ke peningkatan intensitas paramiliter untuk menindas kekuatan-kekuatan patriotik dalam skala lokal atau regional di tengah semakin halusnya aparatur ideologis bekerja membela kepentingan-kepentingan dominan dan mengkondisikan pertumbuhan kesadaran palsu masyarakat.

"Torture", misalnya telah menjadi bagian tindakan aktif penguasa di sejumlah negara. Amnesti internasional (1984) menulis bahwa "torture" seringkali digunakan sebagai bagian integral dari strategi keamanan suatu pemerintahan. Demikian pula halnya "diaapperances" (desa parecido) di beberapa negara Guatemala (1966) Chili (pasca 1973) sebagai contoh merupakan salah satu metode represi paling efektif, ketika skwadronskwadron pembunuh tak resmi dan ganggang paramiliter sayap kanan beroperasi "menghilangkan" lawan-lawan politik mereka. "Disapperances" dan eksekusieksekusi ekstra juducial adalah dua taktik represi yang berhubungan erat. Di negara manapun jenis-jenis kekerasan sebagaimana diuraikan di atas, termasuk "legitimized violence" oleh pihak-pihak yang memonopoli sarana-sarana kekerasan merupakan persoalan tersendiri yang lebih utama dibandingkan bentukbentuk kekerasan individual atau kejahatan-kejahatan dengan kekerasan oleh kelompok-kelompok kriminal.

Ragaan Johan Galtung di bawah ini menunjukkan bahwa mobilitas sosial geografis, , inflasi ekonomi, kultural dan ilmiah, inofasi politik, akan melahirkan semacam tekanan sistematik yang mendorong lahimya aktifitas destruktit baik yang terjadi di dalam sistim maupun di luar sistim seperti revolusi.

\section{Gejala Kota}

Di wilayah perkotaan, pertumbuhan faktor-faktor yang mendorong kelangkaan lingkungan ini tidak lepas kaitannya dengan pengembangan fungsi kota secara administratif maupun komersial yang membutuhkan tersedianya sumber daya air, tanah, energi dan lain-lain yang cukup banyak. Dalam kehidupan kota yang kian sempit dan langka sumber daya di satu sisi, tampilnya kota sebagai simpul interaksi sosial budaya modern yang sarat dengan simbul modernitas serta peningkatan tuntutan kebutuhan warga dan pertambahan daya tarik kota di sisi lain makin membuat eko-sosial kota menjadi medan potensial lahirnya pelbagai konflik sosial yang diakibatkan oleh "deprivasi relatif" yang dialami sebagian warga kota.

Kenyataan semacam itu nyaris terjadi di kota-kota dunia ketiga. Di Áfrika misalnya, Eric Paul Kibuka mengemukakan bahwa konflik kekerasan yang berkembang mempunyai kaitan erat dengan pertumbuhan dan perluasan kota yang ditandai menyempitnya ruang sosial (social space), heterogenitas dan anomitas, perubahan-perubahan sosial, persaingan, orientasi materialistis dan bangkitnya kecenderungan individualisme. Kondisi ini jelas mengurangi pengendalian internal maupun eksternal terhadap kejahatan. Di wilayah perkotaan jelas terdapat banyak kemungkinan untuk persekutuan pelanggar hukum yang akan semakin mempertinggi kualitas kejahatan. Peluang untuk melakukan kejahatan konvensional juga bertambah, sementara kota menyediakan pasaran bagi barangbarang hasil kejahatan. Kota pun seakanakan memberi fasilitas bagi bentuk dan dimensi bagi kriminalitas.

Tidak jauh berbeda, di wilayah pedesaan, kondisi kemiskinan yang 
potensial juga membiakkan faktor-faktor kekerasan secara nyata. Hal itu dialami terutama oleh masyarakat tani Jawa. Dalam jangka waktu 10 tahun (1975-1983) saja misalnya, jumlah petani pemilik lahan kurang dari 0,5 ha bertambah 2,3 juta dan mereka hanya'menguasai $10,5 \%$ dari total lahan pertanian. Sedang petani dengan lahan lebih dari 5 ha yakni 2,3\% menguasai $18,4 \%$ luas tanah pertanian. Ketimpangan serupa juga terjadi dalam pemilikan, penguasaan dan pendayagunaan tanah di daerah perkotaan, sementara penduduk kota-kota di Indonesia membengkak dari 33,1 juta menjadi 42,2 juta. Sedangkan penduduk kota di Jawa bertambah dari 23 juta menjadi 130 juta.

Jumlah penduduk miskin dewasa ini nampaknya tidak bergeser dari kenyataan sekitar 36,5 juta (22\% dari. penduduk Indonesia) termasuk ke dalam kelompk miskin; 8,3 juta diantaranya tinggal di kota-kota dan 28,2 juta orang berada di daerah pedesaan. Perbandingan penduduk kota dengan desa memang terus bergeser dan urbanisasi adalah gejala tak terhindarkan dalam proses pembangunan. Fenomena demikian ini jika kembali kepada analisis Dixon makin memperkuat kekhawatiran bahwa konflik sosial selama ini dan di -masa-masa mendatang akan makin dikondisikan oleh kesenjangan yang akan makin melebar antara jumlah penduduk dengan tersedianya sumber daya yang makin terbatas, terutama di kota-kota.

\section{Perubahan Arah}

Barangakali terlalu sulit dan akan dianggap muskil untuk menyarankan merubah idologi pembangunan kita, selain tidak ada jaminan bahwa perubahan itu akan membuat keadaan menjadi lebih baik, juga karena perubahan itu akan memakan biaya yang tidak sedikit. Karena itu barangkali menarik untuk mengajukan kembali pelbagai seruan, setidaknya dari Soedjatmoko agar dalam tahap 25 tahun kedua bangsa Indonesia, harus menyelenggarakan pembangunan berkesinambungan sesuai dengan amanat GBHN, yaitu menyelenggarakan pembangunan sedernikian rupa sehingga generasi yang akan datang dapat memenuhi keperluan-keperluan mereka. Hal itu akan memerlukan pemakaian sumber daya alam secara bijaksana dengan perencanaan spatial dan pembangunan ekonomi, rehabilitasi lahanlahan kritis, pengelolaan sumber daya pantai, sungai dan laut, kontrol polusi yang efektif, khususnya mengenai limbah toxis.

Akan tetapi di samping semuanya itu kita akan harus juga menangani dua masalah lain yang besar. Pertama, pembatasan, yaitu bekeja sama di bidang internasional untuk mencegah pemanasan bumi agar tidak melewati peningkatan suhu lebih dari 3 reajat celcius, yaitu batas kemampuan manusia, binatang dan banyak tanaman untuk menyesuaikan diri. Kedua, penyesuaian, yaitu mempersiapkan diri menyesuaikan pola kehidupan pada suhu yang lebih tinggi. $\mathrm{Hal}$ itu mungkin akan berarti mengembangkan jenis padi tangkai panjang misalnya seperti di Bangladesh, yang memungkinkan padi tadi tumbuh juga kalupun permukaan air meningkat.

Mungkin juga dikembangkan jenisjenis padi yang tidak memerlukan pupuk buatan dan pestisida kimia, tapi yang mampu mengikat nitrogen secara alamiah dan memakai unsur alamiah untuk memerangi hama dan penyakit. Di samping itu kebutuhan paling mendesak sebagaimana dikemukakan ilmuan India Amulya Kumar N. Reddy (A. Tofíler) adalah tersedianya energi yang didesentralisasikan di daerah pedesaan dan bukannya persediaan besar terpusat di kota-kota besar. Reddy telah mempelajari kebutuhan energi di pedesaan dan menyimpulkan bahwa kebutuhan sebuah desa bisa dengan gampang dipenuhi oleh suatu pabrik kecil biogis yang murah yang mempergunakan 
kotoran manusia dan hewan dari desa itu sendiri. Dan bekerja terus untuk membuktikan bawha ribuan unit pabrik seperti itu jauh lebih berguna, secara ekologis lebih sehat dan lebih ekonomis daripada beberapa mesin generator raksasa, dan terpusatkan.

Justru penalaran semacam inilah yang berada di balik penelitian biogis dan program instalasi di negara-negara seperti Bangladesh sampi Fiji. Indis sendiri sudah mempunyai- 12 ribu pabrik biogis yang berjalan dan menetapkan target 100 ribu. Cina merencanakan 200 ribu pabrik biogis untuk ukuran keluarga yang bisa bekerja di Szechuan.

Persis di luar New Delhi, penulis futuris dan pengusaha kenamaan, Jagdish Kapur, telah merombak $10 \mathrm{akr}$ (kira-kira 4 ha) tanak kering, yang sama sekali tidak produktif menjadi sebuah model yang terkenal di seluruh dunia sebagai "kebun energi matahari" dengan pabrik biogis. Pendek kata krisis energi sebagai salah satu krisis lingkungan telah melahirkan banyak gagasan baru buat produksi energi.

Sudah barang tentu ada berbagai masalah lain yang mengancam sistemsistem penopang hidup di bumi ini. Tapi jelaslah bahwa penguasaan ilmu pengetahuan dan teknologi harus meliputi kemampuan menangani masalahmasalah global, baik pada tingkat nasional, lokal maupun internasional. Tapi perlu pula disadari bahwa dalam menghadapi situasi persaingan yang segera akan tiba, kemauan politik pemerintah untuk membuka diri pada kenyataan bahwa kekalahan suatu negara dalam persaingan global tak dapat dipungkuri akan membuat negara itu menjadi negara marjinal yang syarat dengan konflik-konflik kekerasan yang membutuhkan keterlibatan seluruh potensi bangsa ini untuk mengantisipasinya. Lebih-lebih terdapat banyak sekalikawasan persoalan, dimana tidak ada kepastian ilmiah, dan itu berarti umat manusia sedang memasuki juga suatu masa yang penuh ketidakpastian, yang sulit untuk diterka, dimana manusia akan merasa sangat terancam."*

\section{DAFTAR PUSTAKA}

Lukman Soetrisno, Menuju Masyarakat Partisipatif, Kanisius, 1995

Lester R. Brown (ed) , Dunia di Tepi Jurang Kebinasaan, Obor, 1990

Naskah hasil penelitian, Environmental Scarcity, State Capacity, And Civil Violence, 1996.

Peter. $L$ Berger, Piramida Pengorbanan Manusia, Iqra, 1983.

Soedjatmoko, Dimensi Manusia dalam Pembangunan, LP3ES, 1983

Thomas F. Homer Dixon, Environmental. Scarcities and Violent Conflict: Evidence from Cases, International Scurity, Vol. 19 No. 159 00, 1994.

, The Ingenuity Gap: Can Poor Countris Adapt to Resource Scarsity, Population and Develpoment Review, Vol. 21 September 1995. 